\title{
Determinants of Foreign Direct Investment and its impact on Economic Growth: Evidence from South Asian Association for Regional Corporation (SAARC) Countries
}

\author{
Gunawardhana C. S. ${ }^{1}$ and Damayanthi N. M. M. ${ }^{2}$ \\ Central Bank of Sri Lanka \\ champisg@cbsl.lk1 manel@cbsl.lk²
}

\begin{abstract}
It is argued that Foreign Direct Investment (FDI) inflows benefits the recipient countries by providing capital, technology and long term foreign exchange and bridges savings and investment gap of the recipient country. Further, FDI provides an important role in achieving economic growth in the developing countries. This paper identifies the influential factors that determine FDI inflow in the South Asian Association for Regional Cooperation (SAARC) Countries and empirically investigates the relationship between economic growth and FDI. Further, this study uses time series data from 1980 to 2018 and considered the size of the economy, economic growth, potential of the host market, economic stability, degree of openness, income level and institutional developments in the host country to identify influential factors to determinants of FDI. Analysis reveal that countries with larger Gross Domestic Product (GDP) growth rate can successfully attract FDI and FDI on the other hand, significantly affect economic growth of a country. In addition, it was found that current account balance, financial deepening and trade openness significantly play a crucial role in determining the FDI flows into recipient countries.
\end{abstract}

Keywords: Economic Growth, Foreign Direct Investment, SAARC countries

Copyright: (C) 2019 Gunawardhana C. S. and Damayanthi N. M. M. This is an open access article distributed under the Creative Commons Attribution License, which permits unrestricted use, distribution, and reproduction in any medium, provided the original work is properly cited.

Correspondence: champicsg@cbsl.1k

ORCID of authors: Gunawardhana C. S - https://orcid.org/0000-0002-4775-4518

DOI: http://doi.org/10.4038/kjm.v8i2.7605 


\section{Introduction}

In the present globalised economic environment, most of the economies are integrated with the world through trade and investments. An increase in FDI may be associated with improved economic growth due to the influx of capital, technology and increased tax revenues of the host countries. Host countries often try to channel FDI into new infrastructure and other projects to boost developments. FDI emerged as a main source of investment for most of the Asian countries and it is less volatile and does not show a pro-cyclical behaviour. The recent years have witnessed a rise in FDI in the developing countries. At present, most of developing countries are becoming important destinations of the leading sources of FDI such as U.K, U.S.A, Mauritius, Netherlands, Singapore, Germany, France, Japan, Republic Korea, Switzerland, Japan, China, Singapore, Saudi Arabia, Germany, United Arab Emirates, Malaysia, Canada, Egypt and Norway (ADB, 2017).

Most of the governments in Asian countries are promoting FDI to reach maximum level of economic growth. Inflows to countries have increased by 17 per cent to $\$ 59$ billion in 2018 (UNCTAD, 2018). The largest recipient of FDI in the SAARC is India, supported a 19 per cent increase in FDI inflows to $\$ 38$ billion (World Investment Report, 2017). The initiatives are likely to accelerate infrastructure investment and improve the overall business climate in these countries. According to the World Bank Report (2017), economic growth of
SAARC countries decreased to 6.5 per cent in 2017 from 6.7 per cent in 2016. FDI in India, Pakistan, Bhutan, Bangladesh and Nepal has contributed to the economic growth of these countries by 7.2 per cent, 3.7 per cent, 5.3 per cent 8.0 per cent, 7.5 per cent, respectively. Developing Asia being the number one FDI recipient region by having FDI inflows of $\$ 510$ billion in 2017, accounted for nearly 30 per cent of the total global FDI (Table 1 and 2, Appendix).

The UNCTAD ${ }^{1}$ (2018) survey has projected India as the second most important FDI destination for transitional corporation. Most investments in India has been to telecommunication and manufacturing sectors (Reserve Bank of India, 2013). Pakistan's economy is closely linked to the rest of the world due to its geographical position and high external sector exposure via the resource potential. Pakistan has one of the most liberal foreign investment regimes in South Asia. Pakistan's FDI flows stood at \$ 1,307 million in 2013 compared to \$ 889 million in 2012 (World Investment Report (WIR), 2014). Sri Lanka offers attractive investment opportunities for foreign investors having adopted new policies to attract FDI into the country and appears to offer the most liberal FDI regime in South Asia. The country has recorded the highest ever gross inflows of FDI in 2017 amounting to $\$ 1.63$ billion doubling from the $\$ 802$ million achieved in 2016 and exceeded $\$ 1.61$ billion reported in 2014, reflecting positive foreign investor confidence.

\footnotetext{
${ }^{1}$ United Nations Conference on Trade and Developments
} 
FDI is thought to be beneficial to recipient economies not only by supplementing domestic investments but also providing innovations and technology transfers and enhancing access to foreign markets and competition among countries (Brooks and Sumulong, 2003; World Bank, 1999). Thus, the developing countries which operate with low-level equilibrium trap i.e., low saving rate followed by low investment rate and therefore, low per capita income growth rate may escape from the trap by importing capital from abroad in the form of FDI (Hayami, 2001). According to the Balance of Payment Manual 6 (BPM 6) of the International Monetary Fund (IMF), direct investment has been defined as the category of cross border investments associated with a resident in an economy having control or a significant degree of influence on the management of an enterprise that is resident in another economy.

Primarily, the impact of FDI on economic growth is expected to be twofold. First, through capital accumulation in the recipient economy, i.e. FDI is expected to be growthenhancing by encouraging the incorporation of new inputs and foreign technologies in the production functions of the recipient economy. Second, through knowledge transfers, FDI is expected to augment the existing stock of knowledge in the recipient economy through labour training and skill acquisition. Foreign investors may increase productivity in the recipient economy and FDI can be deemed to be a catalyst for domestic investment and technological progress. The latter depends on the institutional factors, such as the recipient economy's trade regime, legislation and political stability; and scale factors, such as balance of payments constraints and the size of the domestic market for the goods produced via FDI. The consideration of such country specific effects, given the new FDI-related and existing domestic production possibilities, and their evolution overtime, allows for the examination of such FDI-driven cross country or region-specific externalities or spill overs (De Mello, 1999).

Consequently, the effect of FDI on the growth of economies has been a widely discussed topic in empirical studies specially on developing economics. Research shows that an increase in FDI leads to higher economic growth rates in developed countries compared to rates observed in developing countries. However, it was observed that there were limited research studies conducted considering all SAARC countries as a region to determinants of FDI. Maintaining economic and price stability and financial system stability with a view to encourage and promote the development of the productive resources of the country are the core objectives of many central banks. Therefore, to achieve these twin objectives most of the developing countries encourage FDI to sustainable economic growth in the long run. Accordingly, how to identify factors influencing FDI is an important question to be answered to achieve the said two objectives. Accordingly, this study examines the determinants on FDI and its impact on the economic growth of SAARC countries namely Bangladesh, Bhutan, India, Maldives, Nepal, Pakistan and Sri Lanka. 


\section{Problem Statement}

The determinants of FDI and its impact on economic growth has long been a topic of discussions in several countries. These discussions have provided relationship between FDI and economic growth. Even though there are factors influencing FDI have already been identified in many studies, the significance and size of their impact on FDI may vary in terms of countries' national political, economic and legal cultures, traditions and infrastructures, together with the economic objectives and policies pursued by host governments (Bitzenis et al., 2009). Some researchers have identified the influential factors that determine FDI inflows in individual countries, some European region and Asian countries but it was observed that there were limited studied have been conducted to determine FDI inflows and its impact on economic growth in the SAARC region. Accordingly, we expect to investigate determinants of FDI and subsequently concentrating on significant impact of the factors that turn FDI as potential and effective in SAARC countries. Thus, as first part of this study, we focus on investigating influential factors that determine FDI inflows and the second part is the relationship between economic growth and FDI in SAARC countries

\section{Objective of the Study}

Since FDI plays a major role in developing countries, investors specially look at the market size while cost and business friendly environment of the economy. Accordingly, the main objectives of this study are;

1. To identify determinants of FDI in SAARC region
2. To examine the relationship between most influential factors and FDI

3. To examine the impact of FDI on economic growth

\section{Literature Review}

Different studies on FDI and economic growth have revealed diverse findings. Some studies have concluded that FDI has no impact on economic growth, while others found that there is a clear empirical relationship between the two variables. Studies on determinants of FDI considered several macroeconomic and other country specific variables and suggest specially that inflation, low interest rate, low labour cost, education level, trade, economic growth, per capita income, infrastructure and communication are the factors mostly influencing FDI, while political risk, regulatory framework, bureaucratic hurdles and judicial transparency in the host country are insignificant as determinants of FDI or have mixed influence on FDI inflows.

\section{Determinants of FDI}

Though some countries in SAARC show tremendous increase in FDI in recent years, the FDI stock is relatively low compared to other Asian countries (ADB, 2013). Hence, it is necessary to identify what factors determine FDI inflow or what factors are attract more FDI and what motivates home countries to move private investment towards host countries.

UNCTAD (2017) stated that some foreign investors invest in developing countries mainly to serve the host countries' market. Most of the literature found that domestic market size and market potentials would be the major 
factors in attracting foreign investors to a country. Some studies have considered the level of GDP and GDP growth rate as the size of the market and found that GDP has a significant effect on FDI inflow (Root and Ahmed, 1979; Torrisi, 1985; Schneider and Frey, 1985; Wheeler and Mody, 1992; Jun and Singh, 1996; Nunnenkamp and Spatz, 2002; Frank and Hsiao, 2006; Mottaleb, 2007; Bhavan, Changsheng and Chunping, 2011; Roy, 2012). Mottaleb (2007) stated that countries with better physical infrastructure, business friendly environment and also higher per capita GDP and higher GDP growth rate are the attractive factors to receive large amount of FDI. Further, he stated that large domestic market with high GDP growth rate is the major determinant factor on FDI inflows while modern infrastructure, such as telephone and internet also contribute increase in FDI in developing countries. Artige and Nicolini (2005) stated that market size as measured by GDP or GDP per capita is the most robust FDI determinant in econometric studies. Jordaan (2004) mentioned that FDI will move to countries with larger and expanding markets and greater purchasing power, where firms can potentially receive a higher return on their capital and by implication receive higher profit from their investments.

Using pooled cross-section and timeseries data for 49 less-developed countries Gastanagav, Jeffrey and Pashamova (1998) examined the effects of several different types of policy and institutional variables, including corporate tax rates, tariff rates, the degree of openness to international capital flows, exchange rate distortions, contract enforcement, nationalization risk, bureaucratic delay and corruption, and they concluded that host country policies can influence FDI flows primarily through their influence on the advantages of location in the host country. Frenkel, Funke and Stadtmann (2004) used gravity model in panel data for emerging economies and suggest that distance and both home and host country characteristics play a significant role in determining the extent of FDI flows.

Bhavan, Changsheng and Chunping (2011) investigated that determinants and growth effect of FDI for four countries in SAARC using a gravity model. They have shown that distance and both home and host country characteristics play a crucial role in determining the FDI flows into the SAARC regoin while trade openness, human development index, population and infrastructure were identified as significant factors motivating FDI inflow in SAARC. Jha et. Al., (2012) considered GDP, domestic capital formation, interest rate and real effective exchange rate, labour and trade openness for determining FDI in SAARC and the econometric results showed that trade openness, GDP and direct investment have a positive impact on FDI whereas labour had a negative influence. They concluded that SAARC should focus on bolstering the GDP, strengthening the level of direct investment to improve the infrastructure available and focus on increasing trade openness to attract FDI.

Some scholars considered that labour cost, level of education, trade openness, inflation and balance of payment influence FDI. Feenstra and Hanson (1997) showed that low labor cost is a significant determinant factor of FDI while Fung et. Al., (2000) showed that average labor costs are an insignificant 
determinant of FDI. On the other hand, Noorbakhsh, Farhad, and Youssef (2001) showed that skilled labor is a significant determinant of FDI. Kinoshita and Campos (2003) showed the level of education as an insignificant determinant of FDI. Schneider and Frey (1985) concluded that inflation and high balance of payments deficit negatively affect FDI. In addition, Jun and Singh (1996), Mottaleb and Kalirajan (2010), and Hasen and Gianluigi (2009) concluded that there is a positive effect on trade openness with FDI while Brainard (1997) and Wheeler and Mody (1992) estimated that FDI inflows are positively correlated with trade restrictions. Hussain and Kimuli (2012) suggested that market size (GDP per capita) and global integration (tariff) have FDI enhancing effects while an unstable macro environment (high inflation) hampers FDI inflows to developing countries. In addition, they stated that availability of skilled labor (secondary school enrolment rate) and developed financial sector promote FDI. Demirhan and Masca (2008) showed that market size, better infrastructure, trade openness and economic stability have a positive effect on FDI and also low tax rates stimulate FDI. Further, they found the effect of wage on FDI is negatively related but not statistically significant.

Hussain and Kimuli (2012) suggested that developing countries are able to attract FDI by focusing on either increasing their market size or following more liberal trade regimes while increasing the skilled labor and developing financial institutions with moderate and stable inflation may also enable them to attract foreign direct investment.

\section{Impact of FDI on Economic Growth}

Despite some research findings, there appears to be a general theoretical consensus among development economists that FDI inflows are likely to play a critical role in explaining growth of recipient countries. Some studies have paid attention to the endogeneity and causality concepts. In effect, FDI may have a positive impact on economic growth leading to an enlarged market size, which in turn attracts further FDI as well. This is referred to as the market size hypothesis, that is, markets with rapid economic growths tend to give multinational firms more opportunities to generate greater sales and profits and thus become more attractive to their investments.

Some earlier researches have explained that negative association exists between FDI and growth (Griffing, 1970). However, Chenery and Stout (1966) highlighted that FDI has a favourable impact on productivity and growth in developing countries. Herzer et al, (2008) fiund that there exists neither a long-term nor a short-term effect of FDI on growth, in fact, there is not a single country, out of 28 countries under their study where there is a positive unidirectional long-term effect from FDI to GDP. Further, they revealed that there is no clear association between the growth impact of FDI and the level of per capita income, the level of education, the degree of openness and the level of financial market development in developing countries.

Roy (2012) stated that FDI can attempt to upgrade low income or developing economies in Asia by providing knowledge and complementing domestic investments. This study has 
revealed the empirical relationship between FDI and growth is taken up in growth accounting framework and it is found that economic growth can stimulate FDI in majority of the countries in the Asian boarder (China, India, Pakistan, Sri Lanka, Indonesia, Malaysia, Philippines, Singapore and Thailand). He further explained that countries like China, India, Pakistan, Sri Lanka, Philippines and Singapore have impact on FDI and economic growth while there is no such relationship in Malaysia. Certain studies reveal that for FDI to be effective, the host economy should feature certain level of development and be prepared to absorb the new technology, innovations and practices that are linked to FDI. There should also be adequate infrastructure to facilitate the FDI, not only physical but also social and human. Borensztein, Gregorio and Lee (1998) examined that FDI has a positive overall effect on economic growth, although the magnitude of this effect depends on the stock of human capital available in the host economy. They further argued, that the nature of the interaction of FDI with human capital is such that for countries with very low levels of human capital, the direct effect of FDI is negative.

FDI is identified as the major source for a sustainable growth especially in Asian countries, which others are mostly transfer of capital from developed countries benefiting global economies. FDI can accelerate growth in the ways of generating employment in the host countries, fulfilling saving gap and huge investment demand and sharing knowledge and skills through the host countries linkages (Frenkel, Funke and Stadtmann, 2004). Lucas (1993) and Romer (1990) pointed out that human capital is a crucial determinant in the growth process. Merican (2009) evaluated the impact of FDI and Gross Domestic Investments (GDI) on growth in case of four countries in South Asian region and suggests that the FDI is better than GDI for growth only for two countries. The study has focused on the determinants and growth effect of FDI flow, by adopting gravity and endogenous growth models, respectively, in case of Bangladesh, India, Pakistan and Sri Lanka, by employing the system generalized method of moment estimation.

Bhavan, Changsheng and Chunping (2011) investigated the determinants and magnitude of growth effect of FDI considering an endogenous growth model type equation which includes capital, labor and human capital as principle factors and concluded that the effect of FDI on growth rate is average. Frank and Hsiao (2006) analysed FDI, exports, and GDP in East and Southeast Asia countries using time-series and panel data; examined the Granger causality relations between GDP, exports, and FDI among the eight rapidly developing East and Southeast Asian economies. They pointed out that panel data analysis shows the expected results that FDI causes GDP either directly or indirectly through exports, and thus suggest that exports may be a good substitute of, if not complementary to, human capital or financial development in its relationship with FDI and GDP.

The research on this topic has also paid attention to the problem of endogeneity. The correlation between FDI and growth rate could arise from endogenous determination of FDI, that is, FDI itself may be influenced by innovations in the stochastic process governing growth rates. The study of 
Borensztein, Gregorio, and Lee (1998) used lagged values of FDI and log values for GDP to avoid this problem as there is no established technique to solve the problem of endogeneity.

Pradhan (2009) has considered five Asian countries, namely, Thailand, Malaysia, Singapore, Indonesia and Philippine from 1970-2007 and suggested that economic growth and FDI are integrated for all five countries both at the individual level and group level and finds the existence of a long run equilibrium relationship between the two variables. Mehic, Silajdzic and Hodovic (2013) have conducted a cross country analysis on FDI and growth nexus for the South East European countries using OLS (Ordinary Least Square) method whereas they find FDI to be an important catalyst for growth and domestic investment to have a weak relationship with the growth. They have identified that there is no evidence for inverse causality i.e. economic growth causing FDI flows to increase. Jha et. al., (2012) revealed that GDP and direct investment have a positive impact on FDI inflows in South Asian Countries.

\section{Methodology}

\section{Data and Measurement}

This study used time series data from 1980 to 2018 in 7 SAARC countries. The data has obtained from the UNCTAD data base and World Bank Development Indicators (WDI) data base.

The methodology of this study involves empirical analysis by way of an econometrics model and used Im, Pesaran and Shin (2003) (W-Stat) and
Augmented Dickey Fuller (ADFFisher) test for unit root. Panel approach methodology uses for cross sectional time series analysis.

In the use of panel estimation, the use of standard time series analysis, especially on panel unit roots and co-integration of exogenous variables and long-term relationship would be appended to make the estimation Best Liner Unbiased Estimator (BLUE).

\section{Theoretical Model}

Previous studies have mainly focused on the relationship between FDI and economic growth and several macroeconomic variables such as GDP, inflation and interest rates have considered to investigate determinants of FDI. This study considers the size of the economy, stability in macroeconomic environment of the host economy, financial depth of the country, economic stability, degree of openness, infrastructure and institutional developments to investigate determinants of FDI. This study considers the countries with large size of GDP, higher growth and higher income with better physical infrastructure are more successful in FDI inflows. Based on this, the following variables were considered as determinants FDI.

FDI $(\mathrm{Y})=f$ (size of the economy, stability in macroeconomic environment of the host economy, financial depth of the country, economic stability, degree of openness, infrastructure and institutional developments).

$$
F D I=G D P P+I N F+M_{2}+T O+C A B+T E L E+T E X \ldots .(1)
$$


Where;

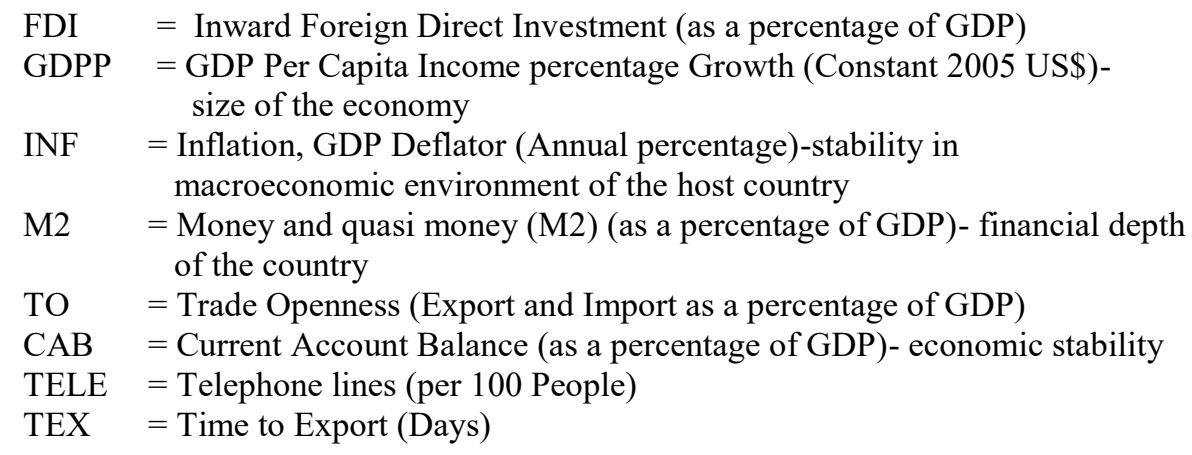

Accordingly, the following formulas were developed for the estimation.

FDI with macroeconomic variables

$$
F D I_{i t}=\alpha_{0}+\alpha_{1} G D P P_{i t}+\alpha_{2} I N F_{i t}+\alpha_{3} l n M 2_{i t}+\alpha_{4} \operatorname{lnTO} O_{i t}+\alpha_{5} C A B_{i t}+\varepsilon_{i t} \ldots
$$

\section{FDI with other qualitative variables}

$$
\begin{aligned}
& F D I_{i t}=\alpha_{0}+\alpha_{1} G D P P_{i t}+\alpha_{2} I N F_{i t}+\alpha_{3} \ln M 2_{i t}+\alpha_{4} \ln T O_{i t}+\alpha_{5} C A B_{i t}+ \\
& \alpha_{6} T E L E_{i t}+\alpha_{7} T E X_{i t}+\varepsilon_{i t} \\
& \varepsilon \text { - error term with white-noise properties } \\
& \alpha_{0}-\text { scalar parameter } \\
& \alpha 1 \text { to } \alpha 7 \text { are the parameters of interest } \\
& \mathrm{i}(\mathrm{i}=1 \ldots 7) \text { - individual countries } \\
& \mathrm{t} \text { - sample years }(1980 \text { to } 2018)
\end{aligned}
$$

FDI is taken as a percentage of GDP instead of the absolute value. GDP Per Capita income (GDPP) growth used as a proxy for market size and Per Capita annual growth used for the estimation. Inflation (INF) percentage annual is considered as macroeconomic parameters considering low and stable inflation indicate overall stability in macroeconomic environment of the host economy. Money and quasi money (M2) is considered under financial deepening as a measure of financial depth of the country and indicates high financial deepening result in lower cost for financial intermediation. M2 used as a percentage of GDP and log value is taken for the estimation. Trade Openness (TO) measures using the ratio of (Export + Imports)/GDP instead of the absolute value of exports or imports to avoid the problem of multi-co linearity and crowding out the effect of other variables on output and assumes high TO would increase FDI inflows to the host country. TO is also used with $\log$ value for the estimation. Current account balance (CAB) indicates overall liberalization of host country and $\mathrm{CAB}$ used as a percentage of GDP for the estimation. Apart from macroeconomic variables, it also tested some infrastructure and policy related variables such as, telephone mainline 
connection per 100 people (TELE) and time to export in days (TEX) to see whether there is an impact on FDI inflows with better infrastructure facilities. In order to check the effects of unobserved variable (omitted variable), which may be correlated with the explanatory variable, it is assumed that unobserved variable changes across the country. Assuming that each country has a unique intercept $\alpha_{i}$ and by definition $\alpha_{i}=\alpha_{0}+\mu \mathrm{Zi}$., the formula 2 and 3 above were developed as follows.

$$
\begin{aligned}
& F D I_{i t}=\alpha_{i}+\alpha_{1} G D P P_{i t}+\alpha_{2} I N F_{i t}+\alpha_{3} l n M 2_{i t}+\alpha_{4} l n T O_{i t}+\alpha_{5} C A B_{i t}+\varepsilon_{i t} \ldots . . \\
& F D I_{i t}=\alpha_{i}+\alpha_{1} G D P P_{i t}+\alpha_{2} I N F_{i t}+\alpha_{3} l n M 2_{i t}+\alpha_{4} l n T O_{i t}+\alpha_{5} C A B_{i t}+ \\
& \alpha_{6} T E L E_{i t}+\alpha_{7} T E X_{i t}+\varepsilon_{i t}
\end{aligned}
$$

\section{Effects of FDI on Growth}

Several research studies investigated the impact of FDI on economic growth under different model specifications and estimated that the FDI inflows mainly contributed to the economic growth (Athukorala, 2003; Balasubramaniam, Salisu, and Sapsford 1996; Frenkel et.al, 2004; Lucas, 1998; Romer, 1990; Merican, 2009). Azman-
Saini, Ahmad, and Siong (2010) followed threshold regression model and found that impact of FDI on growth depends on certain threshold of financial deepening. Barro, and Sala-iMartin (1995) used Cobb-Douglas Production function to estimate growth effect. In order to investigate the impact of FDI, econometric model is illustrated based on a Cobb-Douglas production function as follows.

$$
Y_{i t}=A_{i t} D I_{i t}^{\beta 1} F D I_{i t}^{\beta 2} T O_{i t}^{\beta 3} L F_{i t}^{\beta 4}
$$

$\mathrm{Y}$ - output of the economy measured by real GDP

According to the literature, researchers have used quite a variety of independent variables in their models. Some have used lagged variables in their empirical models (De Mello, 1999). However, for the purpose of this study, the variables are the domestic investment, FDI, TO and Labour Force (LF) (as a proxy of human capital). The following econometric regression function used for the estimation taking the logs on both sides of the above equation.

$$
Y_{i t}=\alpha_{i}+\beta_{1} D I_{i t}+\beta_{2} F D I_{i t}+\beta_{3} T O_{i t}+\beta_{4} L F_{i t}+\mu_{i}+\varepsilon_{i t} \ldots
$$

Gross Capital Formation is obtained as DI and net FDI inflows as ratio to GDP is used as FDI. FDI exerts a positive effect on economic growth according to the degree of complementarily and substitution between FDI and DI (De Mello, 1999). By incorporating the DI variable, the exogenous impact of the
FDI on growth is investigated while controlling the effect of domestic investments. Since the empirical results show that the impact of FDI on growth is superior to that of DI due to technological and knowledge spillovers, it is expected that the effect of FDI would be positive and larger 
than the DI. Further, TO is used as a control variable as empirical studies show that for a host country to take the best advantage of the FDI, it should have more openness to trade as it assures higher competition levels, lesser distortions and greater efficiency in the markets (Balasubramaniam, Salisu, and Sapsford 1996). Labour force as a

\section{Findings and Discussion}

\section{Preliminary Data Analysis}

Table 1 shows descriptive statistics for FDI with all variables for each country. Before moving to conditional empirical estimation, plotted the scatter graphs to check the correlation among the variables (Figure 1, Appendix). Scatter plots indicate that FDI has a positive relationship with growth in GDP per capita, trade openness of host economy percentage of GDP was used as a proxy of human capital (Bhavan et.al., 2011).

Coefficients $\beta 1$ to $\beta 4$ are the output elasticities of the factor inputs and $\mu \mathrm{i}$ indicates set of unobserved sectoral effect and $\varepsilon$ is time and cross section varying shock with standard iid (Independent Identically Distributed) assumptions.

and financial deepening (Money and Quasi Money). On the other hand, as expected, inflation and current account balance are negatively related with FDI. Further, relation with qualitative behaviour, i.e., telephone per 100 person and time to export, which are in line with assumptions have positive scatter plots.

Table 1 Descriptive Statistics for FDI (US\$ Million)

\begin{tabular}{|l|c|c|c|c|c|c|}
\hline \multicolumn{1}{|c|}{ Country } & Mean & Median & Maximum & Minimum & $\begin{array}{c}\text { Standard } \\
\text { Deviation }\end{array}$ & $\begin{array}{c}\text { Obser } \\
\text { vations }\end{array}$ \\
\hline Bangladesh & 0.395000 & 0.080000 & 1.350000 & -0.030000 & 0.477539 & 34 \\
\hline Bhutan & 0.916250 & 0.445000 & 6.170000 & -0.190000 & 1.508952 & 24 \\
\hline India & 0.746364 & 0.580000 & 3.550000 & 0.000000 & 0.877325 & 33 \\
\hline Maldives & 3.882353 & 2.580000 & 14.99000 & -6.010000 & 4.276384 & 34 \\
\hline Nepal & 0.148235 & 0.055000 & 0.530000 & -0.100000 & 0.185137 & 34 \\
\hline Pakistan & 0.941765 & 0.625000 & 3.670000 & 0.100000 & 0.862486 & 34 \\
\hline Sri Lanka & 1.126471 & 1.120000 & 2.850000 & 0.280000 & 0.531133 & 34 \\
\hline & $\mathbf{1 . 1 7 8 0 1 8}$ & $\mathbf{0 . 5 5 0 0 0 0}$ & $\mathbf{1 4 . 9 9 0 0 0}$ & $\mathbf{- 6 . 0 1 0 0 0 0}$ & $\mathbf{2 . 1 4 3 4 6 0}$ & $\mathbf{2 2 7}$ \\
\hline
\end{tabular}

Source: Authors' Calculation 
Gunawardhana C. S., Damayanthi N. M. M., KJM, 2019, 08 (02)

\section{Panel Unit Root Test}

This study used Im, Pesaran and Shin (2003) (W-Stat) and Augmented Dickey Fuller (ADF- Fisher) test for unit root. ADF - Fisher tests allow for individual unit root processes (Maddala and $\mathrm{Wu}, 1999$ ) (Table 2). IPS (W-Stat) Whereas, natural log value of M2 rejects the null hypothesis by 5 per cent level of significance. Log value of TO is stationary at 10 per cent by IPS test and 5 per cent significance level by ADF test.

and ADF-Fishes test for unit root, rejects the null hypothesis of unit root for FDI, GDP growth, GDPP, inflation and $\mathrm{CAB}$, at one percent significant level.

Table 2 Panel Data Unit Root Test

\begin{tabular}{|c|c|c|}
\hline Variables & IPS (W-stat) & $\begin{array}{l}\text { ADF-Fisher } \\
\text { (Chi-square) }\end{array}$ \\
\hline $\begin{array}{l}\text { FDI (percentage of GDP) (Annual } \\
\text { percentage) }\end{array}$ & $-2.185(0.0144)^{* * *}$ & $38.87(0.0004)^{* * *}$ \\
\hline GDP Growth (Annual percentage) & $-9.212(0.000)^{* * *}$ & $95.723(0.000) * * *$ \\
\hline GDPP Growth (Annual percentage) & $-10.375(0.000)^{* * *}$ & $108.38(0.000)^{* * *}$ \\
\hline INF (Annual percentage) & $-4.938(0.000)^{* * *}$ & $52.150(0.000)^{* * *}$ \\
\hline LnM2 (percentage of GDP) & $-1.981(0.023)^{* *}$ & $24.38(0.041)^{* *}$ \\
\hline $\begin{array}{l}\text { CAB (percentage of GDP) (Annual } \\
\text { percentage) }\end{array}$ & $-2.898(0.000)^{* * *}$ & $37.795(0.000)^{* * *}$ \\
\hline D LF (Annual percentage) & $-4.087(0.000)^{* * *}$ & $46.57(0.000)^{* * *}$ \\
\hline LnTO (percentage of GDP) & $-1.278(0.1006)^{*}$ & $23.737(0.0493)^{* *}$ \\
\hline DI (percentage of GDP) & $-2.180(0.014)^{* * *}$ & $27.841(0.001)^{* * *}$ \\
\hline D DI (percentage of GDP) & $-5.877(0.000)^{* * *}$ & $\begin{array}{l}102.049 \\
(0.000) * * *\end{array}$ \\
\hline \multicolumn{3}{|c|}{$\begin{array}{l}\text { Notes: } \\
\text { 1: In level series, test equations are based on individual intercept and trend. } \\
\text { 2. Automatic lag length selection based on AIC: } 1 \text { to } 7 \\
\text { 3. }{ }^{* * *}, * *, * \text { indicate rejection of null hypothesis :Panel Series has a unit root, at } \\
\text { 1percentage,5percentage and } 10 \text { percentage level of significance, respectively. } \\
\text { D: Indicate first difference. }\end{array}$} \\
\hline
\end{tabular}

Source: Authors' Calculation 


\section{Granger Causality Test}

This indicated the causality for seven countries in the SAARC region and $\mathrm{Bi}$ directional Granger Causality has been found in trade openness and FDI.
Further, unidirectional Granger Causality also has been observed for FDI and current account balance, indicating capital inflows under FDI help in narrowing current account balance gap (Table 3).

Table 3 Pair-wise Granger Causality Test

\begin{tabular}{lccc}
\hline Null Hypothesis: & Obs & F-Statistic & Prob. \\
\hline \hline LnTO does not Granger Cause FDI & 219 & 5.13831 & $0.0244^{* *}$ \\
FDI does not Granger Cause LnTO & & 4.17112 & $0.0423^{* *}$ \\
\hline \hline CAB does not Granger Cause FDI & 218 & 0.59922 & 0.4397 \\
FDI does not Granger Cause CAB & & 12.0637 & $0.0006^{* * *}$ \\
\hline \hline
\end{tabular}

Note: Granger Causality test has been applied on the series with 1 lag. .***,**,* indicate rejection of null hypothesis :Panel Series has a unit root, at 1percentage,5percentage and 10percentage level of significance, respectively.

\section{Source: Authors' Calculation}

\section{Determinants of FDI}

The estimated regression models for determinants of FDI under three specifications, Pool, Panel fixed Effect and panel fixed effect with crosssections weights were applied for the estimation purpose. The estimation is employed for formula 2 and 3 above (Table 4).

Under pool estimation, the study followed a naive approach by discounting cross section and time dimensions nature of data and estimated usual OLS and estimated for formula 2 and 3. Estimation result indicates all explanatory variables except inflation in formula 2 are statistically significant and have expected signs with low Rsquare (0.45) and low D-W statistics. Both R-square and D-W statistics improved with inclusion of qualitative variable (formula 3) indicating that quality infrastructure have some explanatory power for FDI inflow in SAARC countries. But this estimation has limitations because of low R-square and $\mathrm{D}-\mathrm{W}$ statistics indicating that there may be autocorrelation in data. Further, pool estimation assumes intercept values for cross section is same, which is a very restrictive assumption.

In this study, it has incorporated unobserved heterogeneity parameters into Models and assumed different intercept for each country in the 
SAARC region. Differentiated intercept for each cross section covers special features of each country. Further, it was assumed that although the intercept differs for each country, $\alpha_{0}$ intercept does not change over time. Accordingly, it estimated formula 4 and 5 using dummy variable technique (differentiated intercept dummies) panel fixed effect. Estimated formula 4 indicates that market size, measured as per capita income growth has positive and statistically significant effect on FDI with desired sign. Other explanatory variable $\mathrm{CAB}$ (deficit for sample countries) and trade openness are highly significant (1 per cent level) with desired sign. Similarly, formula 5 gives similar results, only difference is decline in significance level for market size. Under fixed effect specification, R-square improved (0.77) significantly and $\mathrm{D}-\mathrm{W}$ statistics improved to 0.89 confirming cross sectional variation. It may be noted that, although formula 5 estimation gives desired sign for qualitative variables (telephone/100 people and time to export), the coefficient remained statistically insignificant.

By default, all observations in formula 4 and 5 have equal weight in estimation. This facilitated to check the presence of which looks a restrictive assumption given the nature of macroeconomic environment. To check this, it applied cross section weight in both formula 4 and 5 . cross-section heteroskedasticity. Estimated results with cross section weight indicate the improved result for market size effect on FDI with 1 per cent level. However, once it is incorporated, the qualitative variables market size turns insignificant but $\mathrm{CAB}$ deficit and trade openness remains a statistically significant determinant for FDI. Indicating that opening of the economy with low external vulnerabilities are key determinants of FDI inflow in the SAARC region. Further, with cross section weight, telephone line per 100 people and time to export also become significant determinants for FDI. Although Rsquare declined marginally under crosssection weight model, efficiency improved as D-W statistics increased to 1.06 for formula 4 and 1.17 for formula 5.

Since fixed effect results are significantly different from pool estimation, redundant fixed effect test was applied to test the significance of fixed estimation. Accordingly, Table 7 memo items indicate statistical evidence for fixed effect. Both crosssection $\mathrm{F}$ and cross section Chi-square value statistically support fixed effect in FDI determinants estimation. 
Gunawardhana C. S., Damayanthi N. M. M., KJM, 2019, 08 (02)

Table 4 Determinants of FDI

\begin{tabular}{|c|c|c|c|c|c|c|}
\hline Dependent Variable & \multicolumn{6}{|c|}{ FDI/GDP } \\
\hline Estimation Method & \multicolumn{2}{|c|}{$\begin{array}{c}\text { Pool } \\
\text { Regression }\end{array}$} & \multicolumn{2}{|c|}{$\begin{array}{c}\text { Panel } \\
\text { Fixed Effect }\end{array}$} & \multicolumn{2}{|c|}{$\begin{array}{l}\text { Panel Fixed Effect } \\
\text { (Cross-Section } \\
\text { Weight) }\end{array}$} \\
\hline \multirow{2}{*}{ Variables } & \multicolumn{6}{|c|}{ Formula } \\
\hline & 1 & 2 & 3 & 4 & 3 & 4 \\
\hline $\begin{array}{l}\text { Market-size- } \\
\text { GDPP Growth } \\
\text { percentage }\end{array}$ & $\begin{array}{r}0.0697 * * \\
(1.973)\end{array}$ & $\begin{array}{l}0.0300 \\
(0.937)\end{array}$ & $\begin{array}{r}0.048 * * \\
(1.966)\end{array}$ & $\begin{array}{r}0.044^{*} \\
(1.77)\end{array}$ & $\begin{array}{r}0.040 * * * \\
(2.531)\end{array}$ & $\begin{array}{r}0.024 \\
(1.598)\end{array}$ \\
\hline $\begin{array}{l}\text { Financial deepening } \\
\text { Ln M2 as a percentage } \\
\text { of GDP }\end{array}$ & $\begin{array}{r}0.997 * * * \\
(2.906)\end{array}$ & $\begin{array}{r}0.572^{*} \\
(1.837)\end{array}$ & $\begin{array}{r}0.544 \\
(0.120)\end{array}$ & $\begin{array}{r}0.389 \\
(1.042)\end{array}$ & $\begin{array}{r}0.265 \\
(1.606)\end{array}$ & $\begin{array}{r}-0.006 \\
(-0.034)\end{array}$ \\
\hline $\begin{array}{l}\text { INF (GDP deflator) } \\
\text { annual percentage }\end{array}$ & $\begin{array}{r}-0.027 \\
(-1.078)\end{array}$ & - & $\begin{array}{r}0.025 \\
(1.319)\end{array}$ & $\begin{array}{r}0.019 \\
(0.955)\end{array}$ & $\begin{array}{r}0.019^{* *} \\
(2.057)\end{array}$ & $\begin{array}{r}0.010 \\
(1.069)\end{array}$ \\
\hline $\begin{array}{l}\text { CAB as a percentage of } \\
\text { GDP }\end{array}$ & $\begin{array}{r}- \\
0.0834 * * \\
*\end{array}$ & $\begin{array}{r}- \\
0.073^{* *} \\
*\end{array}$ & $\begin{array}{r}- \\
0.037 * * \\
*\end{array}$ & $\begin{array}{r}- \\
0037 * * \\
*\end{array}$ & $\begin{array}{l}-0.021^{*} \\
(-1.815)\end{array}$ & $\begin{array}{l}-0.019^{*} \\
(-1.762)\end{array}$ \\
\hline $\begin{array}{l}\text { Ln TO as a percentage } \\
\text { of GDP }\end{array}$ & $\begin{array}{r}1.142 * * * \\
(5.268)\end{array}$ & $\begin{array}{r}0.045 * * \\
* \\
(5.074)\end{array}$ & $\begin{array}{r}1.322 * * \\
* \\
(3.661)\end{array}$ & $\begin{array}{r}1.295^{* *} \\
* \\
(3.347)\end{array}$ & $\begin{array}{r}0.937 * * * \\
(5.748)\end{array}$ & $\begin{array}{r}0.892 * * \\
* \\
(5.391)\end{array}$ \\
\hline TELE & - & $0.059 *$ & - & 0.017 & - & $0.036^{* *}$ \\
\hline TEX & - & - & - & -0.031 & - & - \\
\hline Intercept & $\begin{array}{r}-7.300 * * * \\
(0.000)\end{array}$ & $\begin{array}{r}- \\
2.729^{* *} \\
(-2.019)\end{array}$ & $\begin{array}{r}- \\
6.467 * * \\
*\end{array}$ & $\begin{array}{r}- \\
4.809 * * \\
*\end{array}$ & $\begin{array}{r}-3.829 * * * \\
(-8.481)\end{array}$ & $\begin{array}{r}-0.965 \\
(-1.085)\end{array}$ \\
\hline No. of Observations & 195 & 195 & 195 & 195 & 195 & 195 \\
\hline R-Square & 0.45 & 0.57 & 0.77 & 0.77 & 0.67 & 0.71 \\
\hline Adj. R-Square & 0.44 & 0.55 & 0.76 & 0.76 & 0.65 & 0.69 \\
\hline D-W Statistics & 0.44 & 0.55 & 0.89 & 0.89 & 1.06 & 1.174 \\
\hline \multicolumn{7}{|l|}{ Memo: } \\
\hline $\begin{array}{l}\text { Redundant Fixed Effect } \\
\text { Test } \\
\text { Cross Section F } \\
\text { Cross Section Chi } \\
\text { Square }\end{array}$ & - & - & $\begin{array}{l}0.000 \\
0.000\end{array}$ & $\begin{array}{l}0.000 \\
0.000\end{array}$ & $\begin{array}{r}0.000 \\
-\end{array}$ & $\begin{array}{r}0.000 \\
-\end{array}$ \\
\hline
\end{tabular}

Source: Authors' Calculation 


\section{Cross-section fixed effect}

Cross section fixed effect value witnessed different intercepts for each country. The deviation of intercept for Maldives is highest followed by India, whereas Bhutan, Sri Lanka and Nepal have relatively lower deviation for intercept, indicating relatively lower effect of explanatory variables on FDI (Table 5). Average value of intercepts (with cross-section weight) for SAARC is 3.829 for formula 4 and -0.965 for formula 5 (Table 5).

Table 5 Cross Section Fixed Effect with Cross-Section Weight - Intercept

\begin{tabular}{|l|r|r|}
\hline \multicolumn{1}{|c|}{ Country } & $\begin{array}{c}\text { Macroeconomic } \\
\text { Variables }\end{array}$ & $\begin{array}{c}\text { Macroeconomic and } \\
\text { Qualitative Variables }\end{array}$ \\
\hline Bangladesh & -0.100444 & -0.020242 \\
\hline Bhutan & -0.977263 & -0.539805 \\
\hline India & 0.249379 & -0.052185 \\
\hline Maldives & 4.860502 & 4.207347 \\
\hline Nepal & -0.857691 & -0.195526 \\
\hline Pakistan & 0.175635 & 0.081446 \\
\hline Sri Lanka & -0.432129 & -0.871152 \\
\hline
\end{tabular}

Source: Authors' Calculation

\section{Effect of FDI on Growth}

Estimated result indicates FDI effect on growth is positive and statistically significant (Table 6). Other estimation observations are as follows:

1. Formula 6 estimation shows that FDI as a percentage of GDP has positive and statistically significant ( $1 \%$ level) effect on GDP growth in SAARC.

2. Changes in labour also have positive effect on growth.

3. Once it moved to single explanatory variable, estimation result with cross section weight indicates that effect of FDI on GDP growth turn out more significant with increased t-statistics.

4. Redundant fixed effect confirmed fixed effect with cross sectional $F$ and cross section chi square rejects null of fixed effect with $1 \%$ significant level.

5. However, once trade openness was included in the formula, explanatory power of FDI improved significantly with increased t-statistics. 
Gunawardhana C. S., Damayanthi N. M. M., KJM, 2019, 08 (02)

Table 6 Effects of FDI on Growth and Export

\begin{tabular}{|c|c|c|}
\hline Dependent Variable & \multicolumn{2}{|c|}{ GDP Growth } \\
\hline \multirow[t]{2}{*}{ Variables } & \multicolumn{2}{|c|}{ Fixed effect } \\
\hline & GDP Growth & Single Variable Equation \\
\hline DI as a percentage of GDP & -0.007 & - \\
\hline FDI as a percentage of GDP & $\begin{array}{r}0.696 * * * \\
(2.628)\end{array}$ & $\begin{array}{r}0.834 * * * \\
(4.351)\end{array}$ \\
\hline Ln TO as a percentage of GDP & $\begin{array}{r}-1.042 \\
(-0.850)\end{array}$ & - \\
\hline $\mathrm{D} \log \mathrm{LF}$ & $\begin{array}{r}14.161 * * \\
(1.759)\end{array}$ & - \\
\hline GDP Growth & - & - \\
\hline Intercept & $\begin{array}{l}6.146^{*} \\
(1.699)\end{array}$ & $\begin{array}{r}4.451 * * * \\
(17.203)\end{array}$ \\
\hline No. of Observations & 192 & 200 \\
\hline R-Square & 0.21 & 0.169 \\
\hline Adj. R-Square & 0.15 & 0.139 \\
\hline D-W Statistics & 1.75 & 1.724 \\
\hline $\begin{array}{l}\text { Redundant Fixed Effect Test } \\
\text { Cross Section F }\end{array}$ & 0.005 & 0.004 \\
\hline Cross Section Chi Square & 0.004 & --- \\
\hline
\end{tabular}

Source: Authors' Calculation

\section{Cross-section fixed effect}

Cross country fixed effect coefficient indicates country wise variation from the average in intercept of effect on growth (Table 7).
Interestingly, deviation of intercept from mean for FDI effect on growth for Maldives is highest indicating lowest intercept in the region. Intercept for Bhutan is highest followed by India.

Table 7 Country Intercept for Effect of FDI on Growth (with Cross Section Weight)

\begin{tabular}{|l|r|}
\hline \multicolumn{1}{|c|}{ Country } & Economic Growth \\
\hline Bangladesh & 0.135447 \\
\hline Bhutan & 1.724648 \\
\hline India & 1.109969 \\
\hline Maldives & -4.488249 \\
\hline Nepal & -0.056093 \\
\hline Pakistan & -0.478874 \\
\hline Sri Lanka & -0.299013 \\
\hline
\end{tabular}

Source:Authors' Calculation 


\section{Conclusion}

Since this study's principle objectives are to investigate the determinants and growth effect of foreign direct investments in the SAARC region, we applied pool, panel fixed effect models and also checked heteroskedasticity by applying cross section weight in the fixed estimation for determinant FDI analysis and fixed effect for impact on growth analysis.

The results suggest that market size of a country as per GDP per capita growth, current account balance, financial deepening and trade openness significantly play a crucial role in determining the FDI flows into the South Asian region. However, inflation is not a significant factor for FDI flows in the region. In addition, infrastructure and other qualitative variables also show significant influence on FDI flows. Looking at the growth effect of FDI in these countries, FDI is significant on economic growth.

Generally, policy makers recognize FDI inflows as bridging the gap between savings and investments and enhancing factor productivity by technology imports along-with FDI. Nevertheless, experiencing a continuous flow of FDI to the host country will be the policymakers' delight as the benefits of FDI, along with its spillover effects are of immense importance given the current development stage of individual countries.

After establishing stationarity, Granger causality test confirms causal relation between trade openness and FDI inflow. Estimation for FDI determinants indicate that high market size (measured by per capita income growth) and high trade openness of host country attracts more FDI in host country. On the other hand, high $\mathrm{CAB}$ (deficit) adversely affects FDI inflows. On qualitative infrastructure, telephone lines (proxy for quality infrastructure) and time to export (proxy for business environment) have statistically significant and positive effect on FDI inflows. Significant country wise variation in intercept has also been observed indicating diverse effects of determinants on inward FDI.

Estimation of FDI effect on growth is also in line with general economic theory and our formula indicates a positive effect of FDI on growth in SAARC. Cross country variation in intercept has also been observed.

The paper concludes that, market size (high per capita income growth), trade openness and lower current account deficit encourage FDI inflow in SAARC region. Therefore, countries in this region should follow macroeconomic policies for further opening the economy. Surprisingly, inflation (taken as proxy for macroeconomic stability) is insignificant for inward FDI in the region, which is a matter for further discussion. Based on empirical findings, we also suggest that, to attract more FDI in the region, the countries should follow more business friendly environment and increase quality infrastructure.

\section{References}

Agiomirgianakis, G. M., Asteriou, D., and Papathoma, K. (2003). "The Determinants of Foreign Direct Investments; A Panel Data Study for the OECD Countries", Department of Economics City University, London, Working Papers , 03/06. 
Alexander, S. and Ussher, S. (2012), "The voluntary simplicity movement: a multi-national survey analysis in theoretical context", Journal of Consumer Culture, Vol. 12No. 1, pp. 66-86.

Asian Development Bank Report (2013,2014,2015,2016).

Artige, L., and Nicolin, R. (2006). "Evidence on the Determinants of Foreign Direct Investment; The Case of Three European Regions “, HECManagement School , University of Liège , CREPP Working Paper 2006/07.

Athukorala, P.P.A.W. (2003). "The Impact of Foreign Direct Investment for Economic Growth: A Case Study in Sri Lanka", 9th International Conference on Sri Lanka Studies, Matara, Sri Lanka.

Azman-Saini, W.N.W., Ahmad, Z. B., and Siong, Hook Law., (2010). “' Foreign Direct Investment, Economic Freedom and Economic Growth: International Evidence", Economic Modeling, Vol. 27, Issue 5, P 10791089

Balasubramaniam,V. N., Salisu, M., and Sapsford, D., (1996). "Foreign Direct Investments and Growth in EP and IS countries", Economic Journal 106 (1), p 92-105.

Barro, R J., and Xavier, Sala-i-Martin., (1995). "Economic Growth", McGrawHill, Boston.

Bhandari, R., Dharmendra, D., Gyan, Pradhan, and Kamal, U. (2007). "Foreign Aid, FDI and Economic Growth in East European Countries", Economics Bulletin, Vol. 6, No. 13.
Bhavan, T., Changsheng, $\mathrm{Xu}$, and Chunping, Zhong., (2011). "Determinants and Growth Effect of FDI in South Asian Economies: Evidence from a Panel Data Analysis, International Business Research, Vol. 4, No. 1.

Borenzstein, E., Gregorio, J., and JWha, Lee., (1998). "How Does Foreign Direct Investment Affect Growth?", Journal of International Economics, Vol. 45.

Brainard, S. L., (1997). “An Empirical Assessment of the ProximityConcentration Trade-off Between Multinational Sales and Trade", American Economic Review, 87: 4, p 520-544.

Brooks, D. H., Fan, E.X., and Sumulong, L. R., (2003). "Foreign Direct Investment in Developing Asia: Trends, Effects and Likely Issues for the Forthcoming WTO Negotiations", ERD Working Paper, Economics and Research Department, Asian Development Bank.

Central Bank of Pakistan, Annual Report, (2012 to 2018).

Central Bank of Sri Lanka, Annual Report, (2012 to 2018).

Chen, Edward, K.Y., (1993). "Foreign Direct Investment in East Asia", Asian Development Review, Vol. 11, No. 1.

Chenery, H.B., Stout, A., (1966). "Foreign Assistance and Economic Development", American Economic Review (55), p 679-733.

De Mello, L. R. Jr., (1999). "Foreign Direct Investment-led Growth: evidence from time series and panel 
data", Oxford University Paper, 51 (1991), p 133-151.

Demirhan, E., and Mahmut, Masca., (2008). "Determinants of Foreign Direct Investment flows to Developing Countries: a cross-sectional analysis", Prague Economic Papers 4/2008.

Fayyaz, Hussain, Constance, Kabibi Kimuli., (2007). "Determinants of Foreign Direct Investment Flows to Developing Countries", SBP Research Bulletin Volume 8.

Feestra, R. C., and Hanson, G. H., (1997). "Foreign Direct Investment and Relative Wages: Evidence from Mexico's Maquiladoras", Journal of International Economics, 42, p 371393.

Frank, S.T. Hsiao, Mei-Chu, W. Hsiao., (2006). "FDI, Exports, and GDP in East and Southeast Asia-Panel data versus time-series causality analyses", Journal of Asian Economics 17.

Frenkel, M., Funke, K., and Stadtmann, G., (2004). A panel analysis of bilateral FDI flows to Emerging Economies, Economic System, 28, p 281-300.

Fung, K. C., Iizaka, H., Lee, J., and Parker, S., (2000). "Determinants of U.S. and Japanese foreign investment in China. Asian Development Bank Institute", IMF Working Paper, IMF Institute.

Gastanaga,V. M., Jeffrey, B. N., and Pashamova, B., (1998). "Host country reforms and FDI inflows: How much difference do they make?", World Development, 26, 7, p 1299-1314.

Griffin, K., (2009). "Foreign Capital, Domestic Savings and Economic Development, Oxford University
Institute of Economics and Statistics, Bulleting, Vol 32.

Hasen, B. T. and Gianluigi, G., (2009). "The Determinants of Foreign Direct Investment: A Panel Data Study on AMU Countries", Centre for International Banking Economics and Finance Working Paper (November).

Yujiro, Y., (2001). "Development Economics: From Poverty Alleviation to the Wealth of Nations", 2nd Edition, New York, Oxford University Press.

Herzer, D., Klasen, S., and Felicitas, N.L.D., (2008). "In search of FDI-led Growth in Developing Countries: The way forward", Economic Modeling, Volume 25, Issue 5, p 793-1110.

Im, K.S., Pesaran, M.H. and Shin, Y., (2003). "Testing for Unit Roots in Heterogeneous Panels", Journal of Economics, 115:53- (revise version of 1997's work), p 53-74.

International Monetary Fund, (2009). Balance of Payments Manual, sixth edition, $\mathrm{p}$ 100-110.

Jha, G.M., Agrawal, A., Gupta, A., and Mishra, A.K., (2012), "Determinants of FDI in South Asia", International Research Journal of Social Sciences, Vol. 2(1), 1-6, January (2013).

Jordaan, J. C., (2004). "Foreign Direct Investment and Neighbouring Influences", University of Pretoria.

Jun, K. W., and Sing, H., (1996). "The Determinants of Foreign Direct Investment in Developing Countries." Transnational Corporations, Vol. 5, No.2.

Kinoshita, Y. and Campos, N. F., (2003). "Why Does FDI Go Where it 
Goes? New Evidence from the Transition Economies", William Davidson Institute Working Paper, 573.

Lim, Ewe-Ghee., (2001). "Determinants of and the Relation between Foreign Direct Investment and Growth: A Summary of Recent Literature", IMF Working Paper No. 175.

Lucas, Robert E.B., (1993). "On the Determinants of Direct Foreign Investment: Evidence from East and Southeast Asia", World Development, Vol., 21, No. 3,p 391-406.

Maddala, G.S., and Shaowen, Wu., (1999). "A comparative study of unit root tests with panel data and new simple test", Oxford Bulletin of Economics and Statistics, Special issue, p 631-652.

Mehdi, Behname., (2012). "Foreign Direct Investment and Economic Growth: Evidence from Southern Asia", Atlantic Review of Economics.

Mehic, E., Silajdzic, S., Hodovic, V.B., (2013). "The impact of FDI on Economic Growth: some evidence from South East Europe", Emerging Markets Finance and Trade, January-February 2013, Volume 49, Supplement 1, p 520.

Merican, Y., (2009). "Foreign Direct Investment and Growth in Asean-4 Nations, International Journal of Business and Management, 4, N0.6.

Mody, A., Dasgupta, S., and Sinha, S., (1998). "Japanese Multinationals in Asia: Drivers and Attractors", Oxford Development Studies, 27:2, p 149-164.

Mottaleb, K. A., (2007). "Determinants of Foreign Direct Investment and Its
Impact on Economic Growth in Developing Countries", MPRA Paper No. 9457.

Mottaleb, K. A. and Kalirajan, K., (2010). "Determinants of Foreign Direct Investment in Developing Countries: A Comparative Analysis", Australia South Asia Research Centre, ANU Working Paper, 2010/13.

Nair-Reichert, U., Weinhold, D., (2000). "Causality Tests for CrossCountry Panels: New Look at FDI and Economic Growth in Developing Countries", Oxford Bulletin of Economics, 2001.

Noorbakhsh, F., Farhad, Noorbakhsh A. P., and Youssef, A., (2001). "Human Capital and FDI Inflows to Developing Countries: New Empirical Evidence", World Development, 29:9 (September), p 1593-1610.

Nunnenkamp, Peter and Spatz, Julius., (2002). "Determinants of FDI in Developing Countries: has globalization changed the rules of the game?".

Pradhan, R.P., (2009). "The FDI- LedGrowth Hypothesis in Asian- 5 Countries: Evidence from Co integrated Panel Analysis", International Journal of Business and Management, Vol. 04 No. 02.

Reserve Bank of India, Annual Report (2012 to 2018).

Romer, P.M., (1990), "Endogenous Technological Change", Journal of Political Economy 98, S71-S102.

Root, F.R. and Ahmed, A.A., (1979). "Empirical Determinants of Manufacturing Direct Foreign Investment in Developing Countries", 
Economic Development and Cultural Change, Vol. 27,p 751-767.

Ruffin, Roy J., (1993). "The role of Foreign Direct Investment in the Economic Growth of the Asian and Pacific Region", Asian Development Review,Vol.,11, No. 1.

Samrat, Roy., (2012), "Foreign Direct Investment and Economic Growth: An Analysis for Selected Asian Countries"" Kolkata Kumarjit Mandal, University of Calcutta Journal of Business Studies, Quarterly 2012, Vol. 4, No. 1, p 15-24.

Schneider, F. and Frey, B. S., (1985). "Economic and Political Determinants of Foreign Direct Investment", World Development, 13, p 161-175.

Singh, H. and K. Jun., (1996). "The Determinants of Foreign Direct Investment in Developing Countries", Transnational Corporation, 5:2, p 67105.

Torrisi, C.R., (1985). "The Determinants of Direct Investment in a
Small LDC", Journal of Economic Development, Vol., 10.

Trevino, L., and Upadhyaya, K P., (2003). "Foreign Direct Investment and Economic Growth: Evidence from Asian Countries", Transnational Corporations, Vol. 12.

Tsai, Pan-Long., (1994). "Determinants of Foreign Direct Investment and its Impact on Economic Growth", Journal of Economic Development, Vol., 19, No. 1.

Wheeler, D. and Mody, A., (1992). "International Investment Location Decisions: The Case of U.S Firms", Journal of International Economics, 33, p 57-76.

World Investment Report (2012 to 2018), United Nations Conference on Trade and Development (UNCTAD), Geneva. 
Gunawardhana C. S., Damayanthi N. M. M., KJM, 2019, 08 (02)

\section{Annexure}

Table 1 Inward and Outward FD as a percentage of GDP

\begin{tabular}{|c|c|c|c|c|c|c|c|c|c|c|c|}
\hline Country & & $\mathbf{1 9 9 0}$ & $\mathbf{1 9 9 5}$ & $\mathbf{2 0 0 0}$ & $\mathbf{2 0 0 5}$ & $\mathbf{2 0 1 0}$ & $\mathbf{2 0 1 2}$ & $\mathbf{2 0 1 4}$ & $\mathbf{2 0 1 6}$ & $\mathbf{2 0 1 7}$ & $\mathbf{2 0 1 1 8}$ \\
\hline \multirow{3}{*}{ Bangladesh } & Inward & 0.01 & 0.00 & 0.59 & 1.35 & 0.91 & 1.08 & 0.80 & 1.06 & 0.88 & 0.98 \\
\cline { 2 - 13 } & Outward & 0.00 & 0.00 & 0.00 & 0.01 & 0.02 & 0.05 & 0.02 & 0.02 & 0.07 & 0.05 \\
\hline \multirow{3}{*}{ Bhutan } & Inward & 0.53 & 0.02 & 0.24 & 0.76 & 4.75 & 1.31 & 1.61 & -0.57 & 0.40 & 0.45 \\
\cline { 2 - 13 } & Outward & - & - & - & - & - & - & - & - & - & - \\
\hline \multirow{3}{*}{ India } & Inward & 0.07 & 0.58 & 0.75 & 0.87 & 1.60 & 1.29 & 1.69 & 1.96 & 1.55 & 1.95 \\
\cline { 2 - 14 } & Outward & 0.00 & 0.03 & 0.11 & 0.36 & 0.95 & 0.46 & 0.58 & 0.22 & 0.44 & 0.54 \\
\hline \multirow{2}{*}{ Maldives } & Inward & 2.60 & 1.81 & 3.57 & 5.34 & 10.14 & 13.44 & 9.01 & 10.35 & 10.62 & 10.70 \\
\cline { 2 - 13 } & Outward & - & - & - & - & - & - & - & - & - & - \\
\hline \multirow{2}{*}{ Nepal } & Inward & 0.16 & 0.28 & $(0.01)$ & 0.03 & 0.53 & 0.51 & 0.15 & 0.51 & 0.80 & 0.90 \\
\cline { 2 - 12 } & Outward & - & - & - & - & - & - & - & - & - & - \\
\hline \multirow{2}{*}{ Sakistan } & Inward & 0.61 & 1.19 & 0.42 & 2.01 & 1.14 & 0.38 & 0.75 & 0.89 & 0.93 & 1.10 \\
\cline { 2 - 12 } & Outward & 0.00 & 0.00 & 0.02 & 0.04 & 0.03 & 0.03 & 0.05 & 0.02 & 0.02 & 0.05 \\
\hline \multirow{2}{*}{ Lanka } & Inward & 0.54 & 0.43 & 1.06 & 1.12 & 0.96 & 1.58 & 1.13 & 1.10 & 1.57 & 1.75 \\
\cline { 2 - 11 } & Outward & 0.01 & 0.04 & 0.01 & 0.16 & 0.09 & 0.13 & 0.08 & 0.29 & 0.08 & 0.10 \\
\hline
\end{tabular}

Table 2 Inward and Outward FD as a percentage of GDP

\begin{tabular}{|c|c|c|c|c|c|c|c|c|c|c|c|}
\hline $\begin{array}{l}\text { Country } \\
\text { Category }\end{array}$ & & 1990 & 1995 & 2000 & 2005 & 2010 & 2012 & 2014 & 2016 & 2017 & 2018 \\
\hline \multirow{2}{*}{$\begin{array}{l}\text { Developing } \\
\text { Economies }\end{array}$} & Inward & 16.76 & 34.04 & 18.72 & 33.80 & 45.23 & 52.03 & 51.20 & 35.88 & 46.91 & 52.61 \\
\hline & Outward & 4.90 & 15.41 & 11.79 & 15.48 & 27.46 & 30.63 & 36.29 & 27.60 & 26.63 & 28.64 \\
\hline \multirow{2}{*}{$\begin{array}{l}\text { Developing } \\
\text { Economies } \\
\text { Asia }\end{array}$} & Inward & 10.93 & 23.58 & 11.08 & 22.74 & 28.45 & 30.11 & 34.36 & 25.45 & 33.28 & 33.29 \\
\hline & Outward & 4.53 & 12.44 & 7.62 & 10.30 & 18.87 & 22.15 & 32.64 & 26.11 & 24.49 & 28.50 \\
\hline \multirow{2}{*}{$\begin{array}{l}\text { Eastern } \\
\text { Asia }\end{array}$} & Inward & 4.25 & 13.70 & 8.88 & 12.41 & 15.24 & 15.90 & 37.57 & 40.26 & 39.44 & 45.45 \\
\hline & Outward & 3.97 & 9.23 & 6.62 & 6.49 & 13.74 & 15.41 & 63.05 & 74.44 & 65.71 & 68.81 \\
\hline \multirow{2}{*}{$\begin{array}{l}\text { Southern } \\
\text { Asia }\end{array}$} & Inward & 0.10 & 0.82 & 0.34 & 1.46 & 2.04 & 2.48 & 6.05 & 8.09 & 7.76 & 8.89 \\
\hline & Outward & 0.00 & 0.04 & 0.04 & 0.39 & 1.09 & 0.66 & 2.62 & 1.35 & 3.05 & 4.05 \\
\hline \multirow{2}{*}{$\begin{array}{l}\text { South } \\
\text { Eastern } \\
\text { Asia }\end{array}$} & Inward & 6.18 & 8.33 & 1.60 & 4.38 & 6.95 & 8.24 & 18.91 & 18.00 & 19.95 & 20.19 \\
\hline & Outward & 0.96 & 3.35 & 0.72 & 2.05 & 3.15 & 4.36 & 19.29 & 9.58 & 14.45 & 16.45 \\
\hline \multirow{2}{*}{$\begin{array}{l}\text { Western } \\
\text { Asia }\end{array}$} & Inward & 0.39 & 0.72 & 0.25 & 4.50 & 4.22 & 3.49 & 4.59 & 4.59 & 3.36 & 4.45 \\
\hline & Outward & $(0.40)$ & $(0.17)$ & 0.24 & 1.38 & 0.89 & 1.72 & 4.98 & 9.21 & 8.74 & 9.74 \\
\hline \multirow{2}{*}{$\begin{array}{l}\text { Developed } \\
\text { Economies }\end{array}$} & Inward & 83.20 & 64.76 & 80.78 & 62.80 & 49.44 & 41.51 & 87.07 & 169.10 & 106.22 & 112.23 \\
\hline & Outward & 95.10 & 84.42 & 87.95 & 82.37 & 68.43 & 65.38 & 159.76 & 256.10 & 265.04 & 285.04 \\
\hline
\end{tabular}


Gunawardhana C. S., Damayanthi N. M. M., KJM, 2019, 08 (02)

Figure 1 Scatter Plot Diagrams
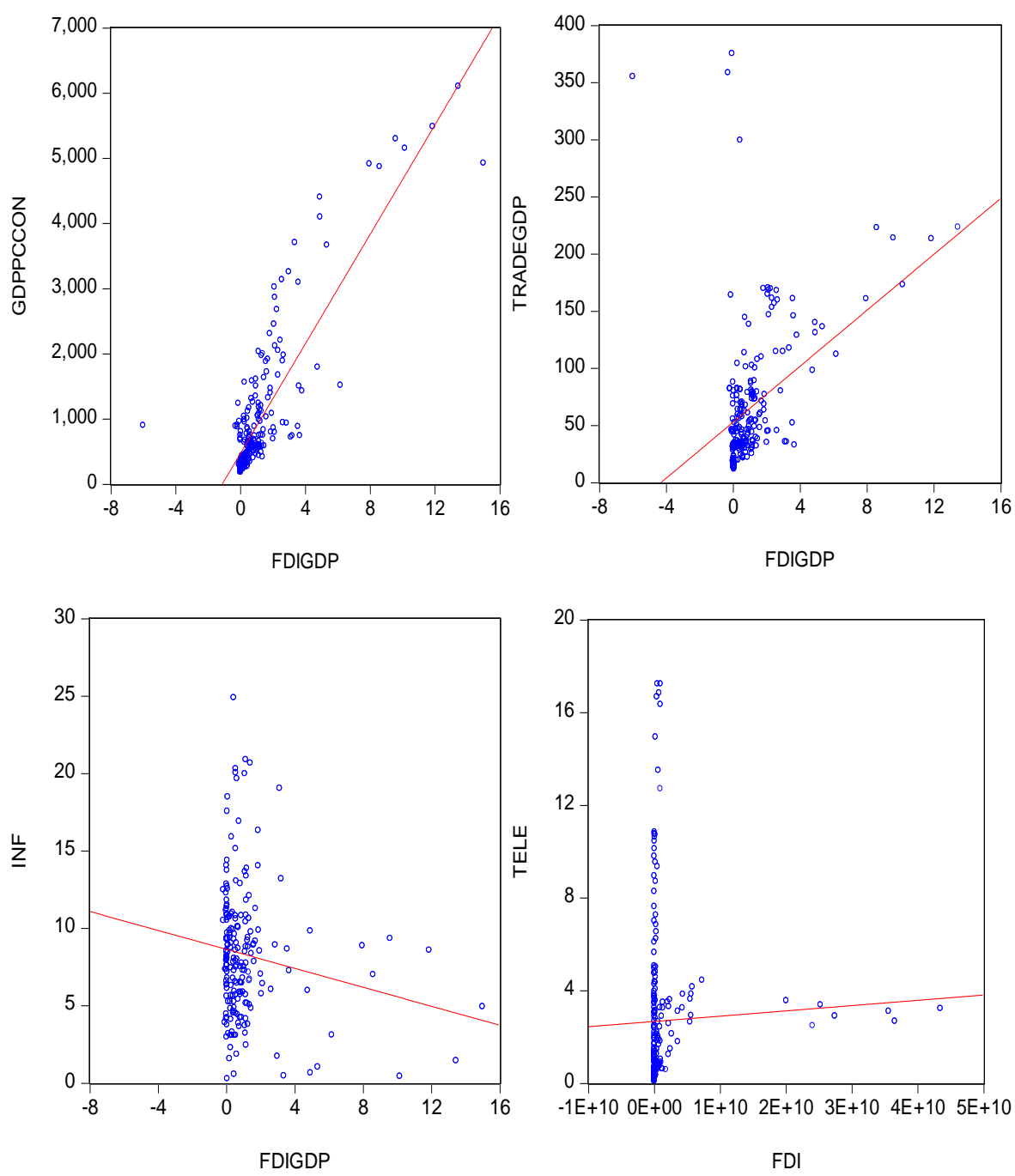

Kelaniya Journal of Management | 2019 | Vol. 08 | Issue 02 | Page 90 
Gunawardhana C. S., Damayanthi N. M. M., KJM, 2019, 08 (02)
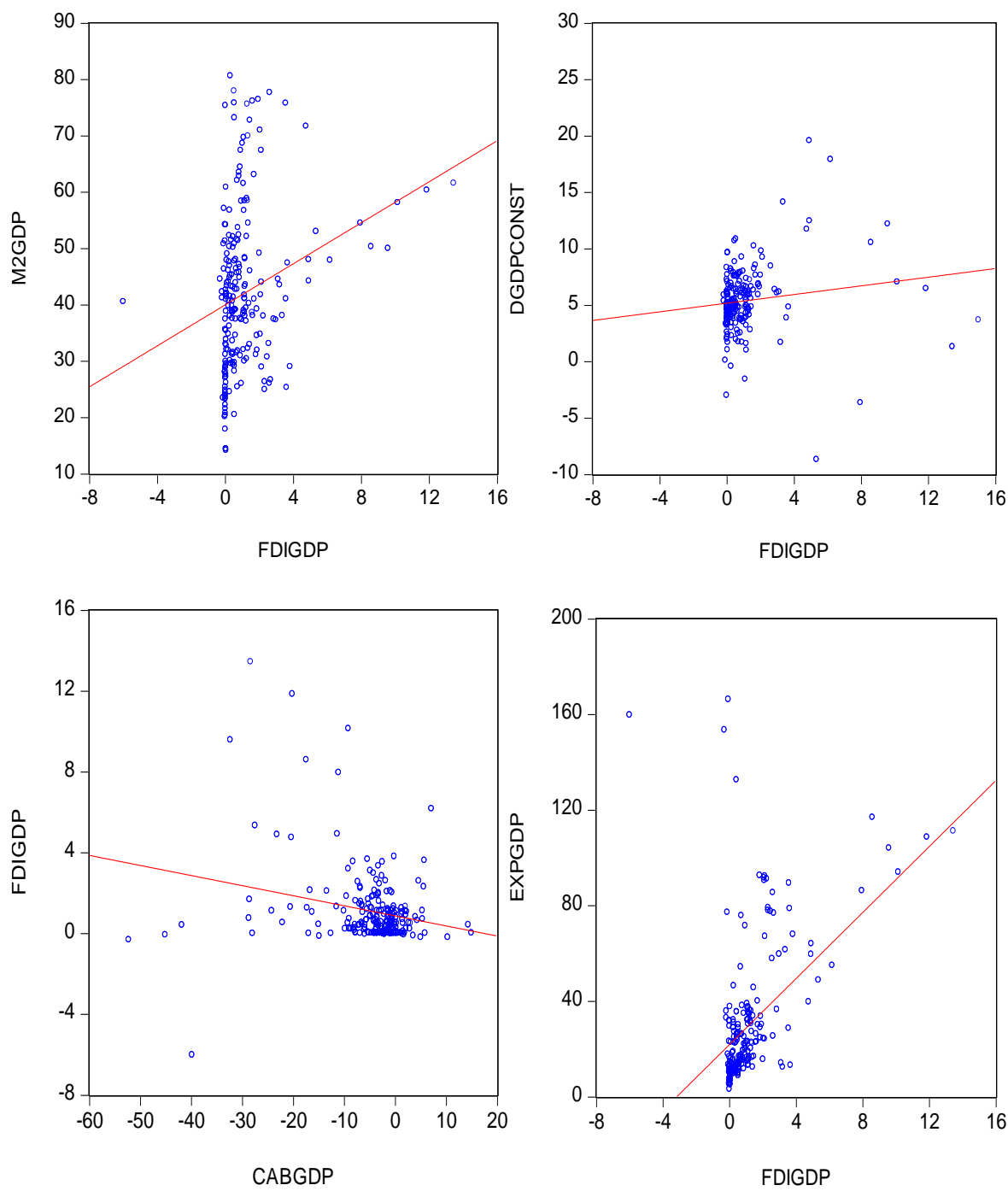